\title{
Study of paediatric renal biopsies with clinicopathologic correlation and comparison with literature on adult renal biopsies
}

\author{
Kirti Khetan ${ }^{1}$, Gunjan Gupta ${ }^{2, *}$, Swarnalata G. ${ }^{3}$ \\ ${ }^{1}$ Consultant Pathologist and Director, Medicare Diagnostics, Hyderabad, ${ }^{2}$ Assistant Professor, ${ }^{3}$ Professor, Dept. of \\ Pathology, ${ }^{2}$ Dr. VRK Women's Medical College, Telangana, ${ }^{3}$ Apollo Hospital, Jubilee Hills, Hyderabad, \\ Telangana, India
}

*Corresponding Author:

Email: drgunjan@ nicehospital.in

\begin{abstract}
Introduction: Renal biopsy is frequently used in complete work-up for renal diseases. The kidney reacts in a limited number of patterns to various injuries and the clinical manifestations corresponding to these reactions are also limited.

Aim of the study: To study the non-neoplastic renal diseases in paediatric population 0-15 year age, to study the differences in the disease prevalence between paediatric and adult population, and to document the geographic variation in renal diseases.

Materials and Methods: The renal biopsies from 0-15 year age group of both genders were studied for light microscopy and immunofluorescence studies. The clinical presentation of the patients such as nephrotic or nephritic or both or as acute renal failure was noted for clinic pathologic correlation. The paediatric renal diseases were compared with adult renal diseases based on literature search. Also the geographic variations were studied and compared based on published data from different countries.

Results: Nephrotic syndrome was the most common clinical presentation for paediatric renal diseases .Minimal change disease $(37.8 \%)$ and FSGS $(22.4 \%)$ cases commonly presented as nephrotic syndrome. PIGN $(37.6 \%$ cases) presented frequently as nephritic syndrome in the paediatric age group.

Conclusion: Nephrotic syndrome is the most common indication for renal biopsy and minimal change disease is the commonest cause of nephrotic syndrome in children. Incidence of membranous nephropathy and IgA nephropathy is relatively less in India. PIGN is the most common cause of acute renal failure in the paediatric age group. In systemic lupus erythematosus, most common presentation is nephrotic syndrome with class IV lupus nephritis being more frequent.
\end{abstract}

Keywords: Acute renal failure, IgA nephropathy, Nephrotic syndrome, Nephritic syndrome, Paediatric age group, Renal biopsy.

Received: $05^{\text {th }}$ July, 2017

\section{Introduction}

Renal biopsy is an invaluable method used in evaluation of renal diseases. The kidney reacts in a limited number of ways to various injuries and the clinical manifestations corresponding to these reactions are also limited. ${ }^{1}$ Spectrum of renal diseases in children is different from adults and a geographic variation also exists. Renal diseases are not uncommon in paediatric age group and their diagnosis is important for treatment and prognosis. Histopathological examination of renal biopsies in a patient with renal disease forms an important part of clinical workup. Along with routine histopathology, immunofluorescence studies are also required in most of the cases and electron microscopy is required in some cases to arrive at a specific diagnosis. The spectrum of renal diseases in developing countries is different from that in developed countries. ${ }^{2}$

\section{Aims and Objectives}

To document the various non-neoplastic lesions in paediatric age group.

To compare the prevalence of diseases in agegroups of 0-5, 6-10 and 11-15 years in our study population.

To correlate clinical findings with histopathology and immunofluorescence results.

To study the differences in the disease prevalence between paediatric and adult population based on literature search.

To document the geographic variation in renal diseases.

\section{Materials and Methods}

This was a retrospective and prospective study carried out in the department of Pathology, Apollo Hospitals, Jubilee Hills, Hyderabad, over a period of twelve years. Only paediatric renal biopsies in age 0-15 year age group received 
during this period were considered. A total of 958 renal biopsies were received out of which 64 $(6.6 \%)$ were inadequate and 95 cases required further extensive studies like electron microscopy and hence, were excluded. So only 799 cases with a definite diagnosis made on light microscopy and immunofluorescence or only light microscopy were included in the study.

Inclusion criteria: Renal biopsies only from paediatric age group 0-15 years were considered.

Exclusion criteria: Inadequate renal biopsies, Biopsies requiring electron microscopy.

Renal biopsies were performed by clinicians. A cutting needle through percutaneous route was used. Two cores were preferred from each case. One core was taken for light microscopy and the other was processed for immunofluorescence study. The biopsies were transported to the laboratory immediately without any delay. The biopsies for light microscopy were fixed in Bouin's fluid and for immunofluorescence the material was received in gauze soaked in cold saline. Michel's transport medium was used if delay more than a few hours was expected. For light microscopy the tissue was fixed for 6 hours in Bouin's fluid followed by overnight fixation in $10 \%$ neutral buffered formalin and then submitted to a short processing. Biopsy cores were serially sectioned and 5 to 6 sections were placed on each slide. Two slides each were attained for hematoxylin and eosin, trichrome and silver methenamine stain. Other stains like Congo red, Verhoff stain were done wherever indicated.

The renal biopsies containing 5 to 10 glomeruli were considered adequate.

The microscopic examination included assessment of glomeruli for: Size, cellularity, segmental or global changes, mesangium, leukocytes, capillary walls, necrosis, thrombi, adhesions to Bowman's capsule, deposits with type and location, crescents with type and percentage, sclerosis with distribution and percentage.

The tubules were examined for: Necrosis, reparative changes, dilatation, casts, cellular inclusions, vacuolization and basement membrane changes.

The blood vessels were examined for: Intimal thickening, elastic changes, hyalinosis, thrombosis, embolism, necrosis, inflammation and juxtaglomerular apparatus.

The interstitium was examined for: Edema, inflammation, type of inflammatory cells and fibrosis.

For immunofluorescence: The positive or negative reactions along with specific components were noted. The pattern of reaction i.e. linear or granular, the intensity and distribution of reaction were noted.

For immunofluorescent technique cryostat sections were taken at 2-5 micron thickness. Sections were dried at room temperature for 15 to 30 minutes. Anti IgG, IgM, IgA, C3c, C1q, fibrinogen, Kappa and Lambda light chains were used. After the light microscopic and immunofluorescent evaluation of the renal biopsies the study was further analyzed in 91 cases with a clinical follow-up for progression of the disease. The findings in this study were compared with other studies. A comparison of incidence of diseases between different groups was performed. A comparison of our findings with adult and elderly population was done. A comparison of the results with same age group in developed and developing countries was done.

\section{Results}

Table 1: Distribution of cases based on clinical presentation and biopsy reports

\begin{tabular}{|l|c|c|c|c|}
\hline \multirow{2}{*}{\begin{tabular}{c} 
Histopathology and \\
\cline { 2 - 5 }
\end{tabular}} & $\begin{array}{c}\text { Nephrotic } \\
\text { syndrome } \\
\text { No. of cases } \\
(\mathbf{\%})\end{array}$ & $\begin{array}{c}\text { Nephritic } \\
\text { syndrome } \\
\text { No. of } \\
\text { cases (\%) }\end{array}$ & $\begin{array}{c}\text { Nephrotic- } \\
\text { Nephritic } \\
\text { syndrome } \\
\text { No. of cases (\%) }\end{array}$ & $\begin{array}{c}\text { Acute renal } \\
\text { failure } \\
\text { No. of cases } \\
\text { (\%) }\end{array}$ \\
\hline MCD & $196(37.8 \%)$ & & & \\
\hline FSGS & $116(22.4 \%)$ & $5(3.6 \%)$ & $6(16.6 \%)$ & \\
\hline Mild DMP & $68(13.1 \%)$ & $8(5.8 \%)$ & $3(8.3 \%)$ & \\
\hline Membranous nephropathy & $30(5.8 \%)$ & $2(1.4 \%)$ & $2(5.5 \%)$ & $1(0.9 \%)$ \\
\hline MPGN & $23(4.4 \%)$ & $4(2.9 \%)$ & $7(19.4 \%)$ & $1(0.9 \%)$ \\
\hline Mesangioproliferative GN & $21(4.0 \%)$ & $3(2.2 \%)$ & $4(11.1 \%)$ & $5(4.6 \%)$ \\
\hline DPGN with PIGN & $14(2.7 \%)$ & $52(37.6 \%)$ & $7(19.4 \%)$ & $15(14.0 \%)$ \\
\hline IgA nephropathy & $5(0.9 \%)$ & $14(10.1 \%)$ & $1(2.8 \%)$ & $3(2.8 \%)$ \\
\hline Lupus nephritis & $18(3.4 \%)$ & $16(11.6 \%)$ & $2(5.5 \%)$ & $1(0.9 \%)$ \\
\hline
\end{tabular}




\begin{tabular}{|l|c|l|l|l|}
\hline Alport's & $2(0.3 \%)$ & & & \\
\hline $\begin{array}{l}\text { Congenital Nephrotic } \\
\text { syndrome }\end{array}$ & $5(0.9 \%)$ & & & $1(0.9 \%)$ \\
\hline $\begin{array}{l}\text { Congenital Nephrotic } \\
\text { syndrome (Finnish type) }\end{array}$ & $2(0.3 \%)$ & & & \\
\hline $\begin{array}{l}\text { Infantile Nephrotic } \\
\text { syndrome }\end{array}$ & $2(0.3 \%)$ & & & $1(0.9 \%)$ \\
\hline $\begin{array}{l}\text { Diffuse mesangial } \\
\text { sclerosis }\end{array}$ & $2(0.3 \%)$ & & & \\
\hline Renal amyloidosis & $2(0.3 \%)$ & & & $1(0.9 \%)$ \\
\hline Sclerosing GN & $2(0.3 \%)$ & $2(1.4 \%)$ & & $1(0.9 \%)$ \\
\hline Segmental necrotizing GN & $2(0.3 \%)$ & & & $4(3.7 \%)$ \\
\hline Chronic GN & $2(0.3 \%)$ & $1(0.7 \%)$ & & \\
\hline End stage renal disease & $1(0.2 \%)$ & & & $2(1.8 \%)$ \\
\hline IgM nephropathy & $1(0.2 \%)$ & & & $8(7.4 \%)$ \\
\hline Vasculitis & $2(0.3 \%)$ & & & \\
\hline Tubulointerstitial nephritis & $1(0.2 \%)$ & $4(2.9 \%)$ & $1(2.8 \%)$ & \\
\hline C1q nephritis & $2(0.3 \%)$ & & & $5(4.6 \%)$ \\
\hline HSP & & $10(7.2 \%)$ & & $24(23.0 \%)$ \\
\hline HUS & & $5(3.6 \%)$ & & $1(0.9 \%)$ \\
\hline Crescentic GN & & $6(4.3 \%)$ & $3(8.3 \%)$ & $1(0.5 \%)$ \\
\hline Thin BMD & & $1(2.9 \%)$ & & $1(0.9 \%)$ \\
\hline Amyloidosis & & & & $1(0.9 \%)$ \\
\hline ATN & & & & $2(1.8 \%)$ \\
\hline Obstructive uropathy & & & & $107(100 \%)$ \\
\hline Fungal nephritis & & & & \\
\hline $\begin{array}{l}\text { Chronic allograft } \\
\text { nephropathy }\end{array}$ & & & & \\
\hline Malignant hypertension & & & & \\
\hline Acute cortical necrosis & & & & \\
\hline AR polycystic kidney & & & & \\
\hline $\begin{array}{l}\text { Non-Hodgkin's } \\
\text { Lymphoma }\end{array}$ & & & & \\
\hline Primary hyperoxalosis & & & & \\
\hline Total (799) & & & & \\
\hline
\end{tabular}

MCD: Minimal change disease, FSGS: Focal segmental glomerulosclerosis, DMP: Diffuse mesangial proliferation, MPGN: membranoproliferative glomerulonephritis, DPGN: Diffuse proliferative glomerulonephritis, PIGN: Post infectious glomerulonephritis, HUS: Hemolytic uremic syndrome, HSP: Henoch Schonlein purpura, BMD: Basement membrane disease, ATN: Acute tubular necrosis, AR: Autosomal recessive

Table 2: Distribution of cases according to age and gender

\begin{tabular}{|l|c|c|c|c|}
\hline \multicolumn{1}{|c|}{ Biopsy findings (No. of cases) } & Age & Male & Female & Total \\
\hline \multirow{3}{*}{ MCD (196) } & $0-5$ & 42 & 20 & 62 \\
\cline { 2 - 5 } & $6-10$ & 48 & 28 & 76 \\
\cline { 2 - 5 } & $11-15$ & 29 & 29 & 58 \\
\hline \multirow{2}{*}{$\begin{array}{l}\text { Mild diffuse mesangial proliferation } \\
\text { FSGS (127) }\end{array}$} & $0-5$ & 12 & 06 & 18 \\
\cline { 2 - 5 } & $6-10$ & 09 & 11 & 20 \\
\cline { 2 - 5 } & $11-15$ & 21 & 20 & 41 \\
\cline { 2 - 5 } & $0-5$ & 08 & 09 & 17 \\
\cline { 2 - 5 } & $6-10$ & 20 & 17 & 37 \\
\hline Membranous glomerulonephritis (35) & $11-15$ & 40 & 33 & 73 \\
\cline { 2 - 5 } & $0-5$ & 02 & 01 & 03 \\
\cline { 2 - 5 } & $6-10$ & 05 & 03 & 08 \\
\hline Mesangioproliferative GN (28) & $11-15$ & 12 & 11 & 24 \\
\hline
\end{tabular}




\begin{tabular}{|l|c|c|c|c|}
\hline \multirow{4}{*}{ MPGN I (37) } & $6-10$ & 01 & 02 & 03 \\
\cline { 2 - 5 } & $11-15$ & 15 & 05 & 20 \\
\cline { 2 - 5 } & $0-5$ & 01 & 02 & 03 \\
\cline { 2 - 5 } & $6-10$ & 03 & 04 & 7 \\
\hline \multirow{4}{*}{ MPGN II (4) } & $11-15$ & 16 & 11 & 27 \\
\cline { 2 - 5 } & $0-5$ & 0 & 0 & 0 \\
\cline { 2 - 5 } & $6-10$ & 0 & 0 & 0 \\
\hline \multirow{5}{*}{ DPGN with PIGN (73) } & $11-15$ & 1 & 03 & 04 \\
\cline { 2 - 5 } & $0-5$ & 01 & 04 & 05 \\
\cline { 2 - 5 } & $6-10$ & 18 & 04 & 22 \\
\hline \multirow{5}{*}{ HSP (10) } & $11-15$ & 20 & 26 & 46 \\
\cline { 2 - 5 } & $0-5$ & 0 & 0 & 0 \\
\cline { 2 - 5 } & $6-10$ & 2 & 0 & 2 \\
\cline { 2 - 5 } & $11-15$ & 5 & 3 & 8 \\
\cline { 2 - 5 } & $0-5$ & 01 & 0 & 01 \\
\cline { 2 - 5 } & $6-10$ & 02 & 02 & 04 \\
\hline Lupus nephropathy (23) & $11-15$ & 11 & 04 & 18 \\
\cline { 2 - 5 } & $0-5$ & 0 & 04 & 04 \\
\cline { 2 - 5 } & $6-10$ & 0 & 03 & 03 \\
\hline
\end{tabular}

In lupus nephritis, the class-wise distribution was: Class $1-1$ case, Class 2- 8 cases, Class $3-7$ cases, Class $4-14$ cases and class 5- 7 cases and Class 6- zero cases.

In Class 3; 4 cases showed mild to moderate activity with no chronicity and in Class 4; 2 cases showed significant activity with no chronicity and 12 cases showed mild to moderate activity with no chronicity.

In the MCD (196 cases), 33 and 36 cases, in mild diffuse mesangial proliferation 17 and 21 cases, in FSGS 11 and 30 cases, were steroid dependent and steroid resistant respectively.
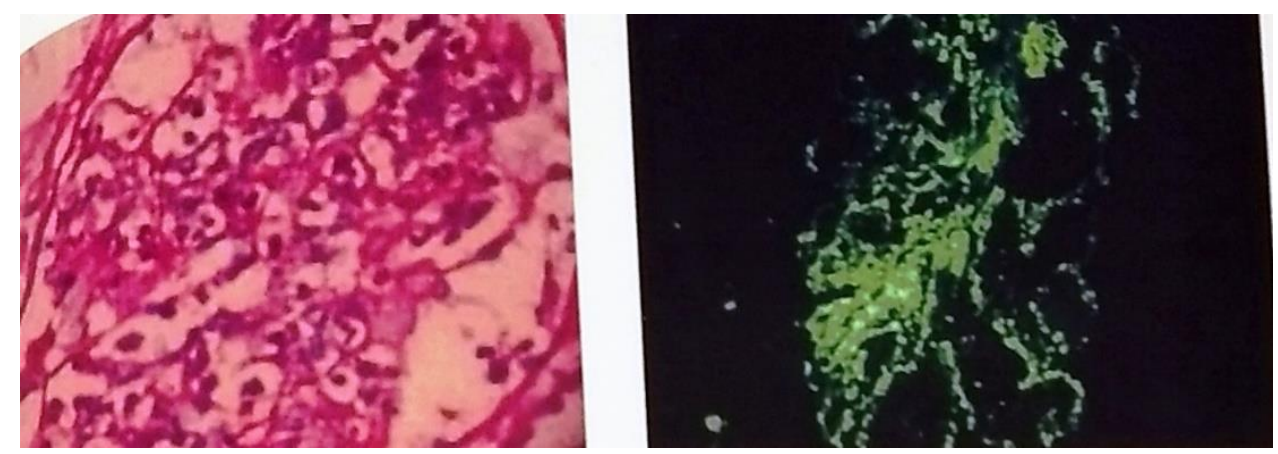

Fig. 1: Post infectious glomerulonephritis (PAS stain 400X and immunofluorescence C3c 400X)

\section{Discussion}

Table 3: Comparison of nephrotic syndrome in paediatric age group

\begin{tabular}{|c|c|c|c|c|c|c|}
\hline$\stackrel{\vec{E}}{\text { D }}$ & $\begin{array}{l}y \\
\tilde{y} \\
\tilde{y} \\
\dot{0} \\
\dot{0} \\
\dot{z}\end{array}$ & $\begin{array}{l}0 \\
0 \\
2\end{array}$ & 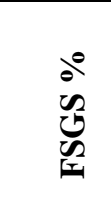 & $\begin{array}{l}0^{0} \\
\mathbf{Z} \\
\vdots \\
z\end{array}$ & 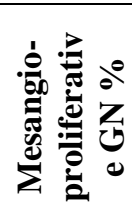 & 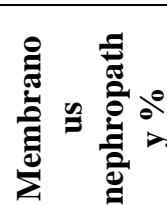 \\
\hline Kumar et al ${ }^{3}$ (India) & 290 & $32.0 \%$ & $34.0 \%$ & $15.0 \%$ & $11.0 \%$ & $2.0 \%$ \\
\hline $\begin{array}{l}\text { Simpson et } \mathrm{al}^{4} \text { (New } \\
\text { Zealand) }\end{array}$ & 157 & $37.0 \%$ & $19.0 \%$ & $23.0 \%$ & - & - \\
\hline $\begin{array}{l}\text { Al-Rasheed et } \quad \mathrm{al}^{5} \\
\text { (Saudi Arabia) }\end{array}$ & 128 & $23.3 \%$ & $24.0 \%$ & $24.0 \%$ & - & - \\
\hline
\end{tabular}




\begin{tabular}{|c|c|c|c|c|c|c|}
\hline $\begin{array}{l}{\text { Chen et } \mathrm{al}^{6}} \\
\text { (Taiwan) }\end{array}$ & 347 & $17.8 \%$ & - & $1.2 \%$ & $26.9 \%$ & $9.8 \%$ \\
\hline Coppo et al $^{7}$ (Italkid) & 432 & $11.6 \%$ & $8.5 \%$ & $5.5 \%$ & $9.5 \%$ & $5.0 \%$ \\
\hline Ko et $\mathrm{al}^{8}$ (Korea) & 662 & $57.0 \%$ & $21.0 \%$ & - & - & - \\
\hline $\begin{array}{lll}\begin{array}{l}\text { White et } \\
\text { (Birmingham) }\end{array} & \mathrm{al}^{9} \\
\end{array}$ & 145 & $74.2 \%$ & $9.3 \%$ & $7.0 \%$ & $5.4 \%$ & $1.5 \%$ \\
\hline Yahya et $\mathrm{al}^{10}(\mathrm{UAE})$ & 490 & $26.2 \%$ & $15.4 \%$ & $26.6 \%$ & - & $28.3 \%$ \\
\hline $\begin{array}{l}\text { Absar et al } \\
{\text { (Pakistan) })^{11}} \text { al }\end{array}$ & 41 & $37.0 \%$ & $12.0 \%$ & $10.0 \%$ & $2.0 \%$ & $7.0 \%$ \\
\hline Present (India) & 518 & $37.8 \%$ & $22.4 \%$ & $4.4 \%$ & $3.0 \%$ & $5.8 \%$ \\
\hline
\end{tabular}

In our study, 54\% (518/958) of the individuals presented with nephrotic syndrome which was considerably less than the observations made by Ko et al, ${ }^{4} 67 \%$, Diouf et $\mathrm{al}^{[12]}$ at Senegal $67 \%$, and McKinney et $\mathrm{al}^{[13]}$ in Yorkshire $88 \%$.

As mentioned in Table 3, the prevalence of MCD in this study was $37.8 \%$ which is higher than the studies conducted by Kumar et al, ${ }^{3}$ Rasheed et al, ${ }^{5}$ Chen et al, ${ }^{6}$ Coppo et al, ${ }^{7}$ Yahya et al, ${ }^{10}$ and similar in studies by Simpson et $\mathrm{al}^{4}$ at $37 \%$ and Absar et $\mathrm{al}^{11}$ at $37 \%$. However with the exception of the observation made by $\mathrm{Ko}$ et $\mathrm{al}^{4}$ and White et $\mathrm{al}^{9}$ who found higher frequency of MCD at $57 \%$ and $74.2 \%$. Our study as in other studies mentioned above shows that minimal change nephropathy is the commonest cause of a steroid resistant/dependent nephrotic syndrome in children.

The prevalence of FSGS in this study (22.4\%) was similar to the studies conducted by Ko et $\mathrm{al}^{8} 21 \%$ and Rasheed et $\mathrm{al}^{5} 24 \%$ while it was significantly lower than the observation made by Kumar et $\mathrm{al}^{3} 38 \%$. Observations made by Simpson et $\mathrm{al}^{4} 19 \%$, Coppo et $\mathrm{al}^{7} 8.5 \%$, White et $\mathrm{al}^{9} 9.38 \%$, Yahya et $\mathrm{al}^{10} 15.4 \%$, and Absaret $\mathrm{al}^{11} 12 \%$ showed significantly lower frequency. In our study, 14 out of 127 patients had varying degree of renal insufficiency and this is as expected in FSGS.

Study conducted by Chen et $\mathrm{al}^{6}$ showed lower prevalence of MPGN (1.2\%) in comparison to our study where it was $4.44 \%$. Coppo et $\mathrm{al}^{7}$ observed $5.5 \%$, White et al as $7.03 \%$, Absar et $\mathrm{al}^{11} 10 \%$, Kumar et $\mathrm{al}^{3} 15 \%$, Simpson et $\mathrm{al}^{4} 23 \%$, Rasheed et $\mathrm{al}^{5} 24 \%$, Yahya et $\mathrm{al}^{10} 26.6 \%$, showed higher frequency of MPGN. Our figures seem to be between those in the West and studies from Africa, Jordan and Arabia.
The prevalence of mesangioproliferative glomerulonephritis in the present study was 3\% and significantly lower than the studies of White et $\mathrm{al}^{9} 5.4 \%$, Coppo et $\mathrm{al}^{7} 9.5 \%$, Kumar et $\mathrm{al}^{3}$ $11 \%$, Chen et $\mathrm{al}^{6} 26.9 \%$ and Hameed et $\mathrm{al}^{11}$ $33.6 \%$.

Membranous nephropathy (MN) had higher frequency in studies conducted by Chen et al $9.8 \%$, Yahya et $\mathrm{al}^{10} 28.3 \%$. In Taiwan, the membranous nephropathy was secondary to hepatitis B antigenemia and the prevalence was significantly lower in the studies conducted by Kumar et $\mathrm{al}^{3}$ at $2 \%$, White et $\mathrm{al}^{9} 1.5 \%$. In the present study MN was $5.8 \%$ cases, which is similar to the observation of Coppo et $\mathrm{al}^{7}$ of $5 \%$. None of our patients were HIV or HBSAg positive or had any other findings to suggest secondary membranous glomerulonephritis.

The study conducted by $\mathrm{Yap}$ et $\mathrm{al}^{14}$ in Singapore found higher frequency of FSGS, mild diffuse mesangial proliferation, mesangioproliferativeglomerulonephritis, membranous nephropathy, diffuse mesangial sclerosis and diffuse sclerosingglomerulonephritis while the prevalence of crescentic glomerulonephritis diffuse endocapillary glomerulonephritis were higher in this study.

Haas et $\mathrm{al}^{2}$ in Chicago, USA had a higher frequency of thin basement membrane disease, Alport's disease, IgA nephropathy and MCD than the present study. Briganti et $\mathrm{al}^{15}$ in Australia had glomerular lupus, FSGS, IgA nephropathy and MCD as the common glomerular pathologies in children. Ko et $\mathrm{al}^{8}$ found higher prevalence of DPGN and PIGN with nephritic presentation.

The study done by Yap et $\mathrm{al}^{14}$ in Singapore showed lower prevalence of DPGN with PIGN. 
Table 4: Comparison with adult nephrotic syndrome

\begin{tabular}{|c|c|c|c|c|c|c|c|}
\hline$\stackrel{\vec{E}}{E}$ & 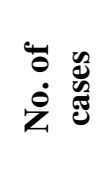 & 己 & $\bigcup_{\mathscr{1}}^{\infty}$ & 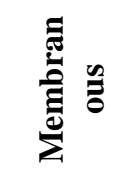 & $\sum_{0.0}^{Z}$ & 号 & 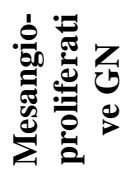 \\
\hline $\begin{array}{l}\text { Woo et } \mathrm{al}^{16} \\
\text { (Singapore) }\end{array}$ & 100 & $15.0 \%$ & - & $5.0 \%$ & $4.0 \%$ & $13.0 \%$ & $60.0 \%$ \\
\hline $\begin{array}{l}\text { Diouf et } \mathrm{al}^{12} \\
\text { (Dakar) }\end{array}$ & 115 & $6.0 \%$ & $47.0 \%$ & $6.0 \%$ & $5.0 \%$ & $13.0 \%$ & $1.0 \%$ \\
\hline $\begin{array}{l}\text { Haas et al }^{2} \\
\text { (Chicago) } \\
\text { Earlier } \\
\text { decade/Later } \\
\text { decade }\end{array}$ & $\begin{array}{lll}- & \text { r }\end{array}$ & $\begin{array}{c}23.0 \% \\
-\end{array}$ & $\begin{array}{l}15.0 \% / \\
35.0 \%\end{array}$ & $\begin{array}{c}36.0 \% / \\
33.0 \%\end{array}$ & $-/-$ & $-/-$ & $-/-$ \\
\hline $\begin{array}{l}\text { Rychik et al } \\
17 \text { (Czech } \\
\text { Republic) }\end{array}$ & 4004 & $12.4 \%$ & - & - & $34.5 \%$ & - & $11.3 \%$ \\
\hline $\begin{array}{l}\text { Present } \\
\text { (India) }\end{array}$ & 518 & $37.8 \%$ & $22.4 \%$ & $5.8 \%$ & $2.0 \%$ & $3.7 \%$ & $3.0 \%$ \\
\hline
\end{tabular}

As mentioned in Table 4, comparative analysis with the adult nephrotic syndrome revealed: MCD in this study was $37.8 \%$ which is less than in adults as expected. Mesangioproliferative glomerulonephritis presents as nephrotic syndrome more commonly in adults.

The incidence of IgA nephropathy in this study is far less than in other studies.

Briganti et $\mathrm{al}^{15}$ in Australia found the common glomerulonephritis in adults in order of frequency were IgA nephropathy, FSGS, lupus and vasculitis.

Lai et $\mathrm{al}^{18}$ in Hong Kong conducted a study on 961 adult cases and showed MCD as the most common cause of NS which was similar to our study. The frequency of MPGN, FSGS and MN were similar to this study. MN was associated with hepatitis B antigenemia. Prevalence of IgA nephropathy was higher in other studies ${ }^{2,12,16,17}$ as compared to our study.

Comparison with nephrotic syndrome in elderly: Moulin et $\mathrm{al}^{18}$ have observed $31.8 \% \mathrm{MCD}, 27.2 \%$ membranous nephropathy and $22.7 \%$ amyloidosis in the elderly with nephrotic presentation. Kingswood et $\mathrm{al}^{19}$ have observed $4 \%$ and $33 \%$ cases of MCD and membranous nephropathy respectively with nephrotic presentation whereas, Haas et al have reported $16.8 \%$ cases and $9.6 \%$ of membranous nephropathy and amyloidosis presenting as nephrotic syndrome. Prevalence of MCDwas higher in present study in paediatric age group. MN was more prevalent in other studies. ${ }^{2,19}$ Study by Haas et $\mathrm{al}^{2}$ showed higher incidence of myeloma kidney and necrotizing vasculitis.

Table 5: Paediatric acute renal failure (ARF)

\begin{tabular}{|l|c|c|c|c|}
\hline \multicolumn{1}{|c|}{ Diseases } & ${\text { Yoshiya et } \mathbf{a l}^{\mathbf{2 0}}}$ & Shah et al $^{\mathbf{2 1}}$ & Olowo et $^{\mathbf{2 2}}$ & $\begin{array}{c}\text { Present } \\
\text { study }\end{array}$ \\
\hline HUS & $35.5 \%$ & $12.0 \%$ & $5.5 \%$ & $4.6 \%$ \\
\hline TIN & $21.1 \%$ & - & $2.8 \%$ & $4.6 \%$ \\
\hline IgANepropathy & $10.0 \%$ & - & - & $2.8 \%$ \\
\hline MPGN & $8.9 \%$ & - & - & $0.9 \%$ \\
\hline Lupus & $5.5 \%$ & - & - & $0.9 \%$ \\
\hline PIGN & $4.4 \%$ & $6.0 \%$ & - & $14.0 \%$ \\
\hline $\begin{array}{l}\text { Acute cortical } \\
\text { necrosis }\end{array}$ & $1.1 \%$ & $18.2 \%$ & - & $3.7 \%$ \\
\hline ATN & - & $66.6 \%$ & - & $6.4 \%$ \\
\hline HSP & $1.1 \%$ & - & - & - \\
\hline ANCA GN & $1.1 \%$ & - & - & - \\
\hline Crescentic GN & - & $6.0 \%$ & - & $23.0 \%$ \\
\hline Cortical & - & $6.0 \%$ & - & $2.8 \%$ \\
\hline
\end{tabular}




\begin{tabular}{|l|c|c|c|c|}
\hline necrosis & & & & \\
\hline $\begin{array}{l}\text { Burkitt's } \\
\text { lymphoma }\end{array}$ & - & - & $47.2 \%$ & - \\
\hline $\begin{array}{l}\text { Glomeruloneph } \\
\text { ritis }\end{array}$ & - & - & $27.8 \%$ & - \\
\hline
\end{tabular}

TIN: Tubulointerstitial nephritis, ANCA GN: Anti neutrophil cytoplasmic antibody GN

As mentioned in Table 5, Yoshiya et $\mathrm{al}^{20}$ in Japan conducted a study on paediatric acute renal failure (ARF) which showed higher incidence of Hemolytic uremic syndrome, tubulointerstitial nephritis, IgA nephropathy, MPGN and lupus nephritis.

Study conducted by Shah et $\mathrm{a}^{21}$ in Bombay on Paediatric age group ARF had higher incidence of acute tubular necrosis, HUS, acute cortical necrosis, glomerulonephritis and patchy cortical necrosis. This study showed higher incidence of crescentic glomerulonephritisand PIGN.

Olowo et $\mathrm{al}^{22}$ found higher incidence of HUS and glomerulonephritis. Many of the cases with ARF were secondary to Burkitt's lymphoma. In our study there were a few additional causes for ARF such as autosomal recessive polycystic kidney disease, non-Hodgkin's lymphoma, mesangioproliferativeglomerulonephritis, MN, primary hyperoxalosis, diffuse mesangial sclerosis, congenital NS, obstructive uropathy, fungal nephritis, segmental necrotizing glomerulonephritis, chronic allograft nephropathy, necrotizing vasculitis and amyloidosis.

Table 6: Comparison of paediatric ARF with adult ARF

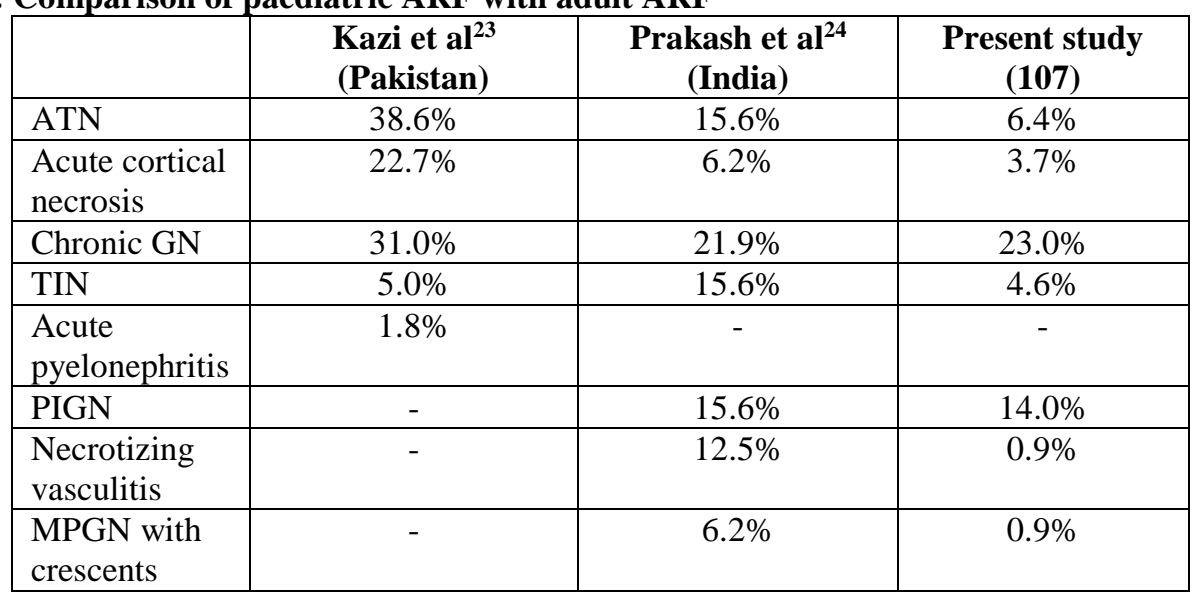

As mentioned in Table 6, Kazi et $\mathrm{al}^{23}$ in Pakistan found higher incidence of acute tubular necrosis, acute cortical necrosis, chronic glomerulonephritisand similar incidence of tubulointerstitial nephritis.

Prakash et $\mathrm{al}^{24}$ from $\mathrm{BHU}$, India found higher incidence of ATN (15.6\%). Study done by Dagger et $\mathrm{al}^{25}$ USA found lower incidence of FSGS leading to ARF.

A study conducted by Haas et $\mathrm{al}^{26}$ showed higher incidence of crescentic glomerulonephritis (31.2\%) acute tubulointerstitial nephritis (18.6\%), ATN (14.2\%), Anti GBM nephropathy (4\%) leading to renal failure in elderly population above 60 years.

Prevalence of IgA nephropathy (3.6\%) was similar to present study. Other conditions like atheroemboli, light chain cast nephropathy and benign nephrosclerosis which they encountered were not seen in paediatric age group in our study.

Study conducted by Kari et $\mathrm{al}^{27}$ in UAE found MPGN presented in earlier age groups whereas in our study it was observed in later age groups.

Utsumomiya et $\mathrm{al}^{28}$ in Japanese children and Johnson et $\mathrm{al}^{29}$ (in Leed) in adults found higher incidence of IgA nephropathy. For school children in Japan, routine urine analysis screening is mandatory which possibly explains the higher detection rate for IgA nephropathy in Japan. ${ }^{30}$

\section{Conclusion}

Nephrotic syndrome is the most common indication for renal biopsy and minimal change disease is the commonest cause of nephrotic syndrome in children. Incidence of membranous nephropathy is lower in India as compared to 
East Asian and African countries. $\operatorname{IgA}$ nephropathy is relatively less prevalent as compared to Western countries. Mild mesangial proliferation is the most common morphology seen in $\operatorname{Ig}$ A nephropathy. PIGN is the most common cause, whereas, HUS is an uncommon cause of acute renal failure in the paediatric age group. In systemic lupus erythematosus, most common presentation is nephrotic syndrome with class IV lupus nephritis being more frequent. The causes for paediatric ARF are different from causes of adult ARF as observed on literature search. Though light microscopy and immunofluorescence are mandatory for evaluation of renal diseases, they have their own limitations and there are many renal lesions which specifically require electron microscopy for definite diagnosis.

\section{References}

1. Habib R. A story of glomerulonephritis: a pathologist's experience. Paediatric Nephrol1993;7:336-46.

2. Haas M, Meehan SM, Karrison TG, Spargo BH. American Journal of Kidney Disease 1997;30(5):621-31.

3. Kumar J, Gulati S, Sharma AP, Sharma RK, Gupta RK. Histopathological spectrum of childhood nephrotic syndrome in indian children. Pediatr Nephrol 2003;18(7)657-60

4. Simpson AK, Wong W, Morris MC. Paediatric nephrotic syndrome in Auckland, New Zealand. J Paediatr Child Health 1998;34(4)360-62.

5. Al-Rasheed, al-Mugeiren MM, Al-Salloum AA, Shaibani MO. Childhood renal diseases in Saudi Arabia: A clinic pathological study of 167 cases. Int Uro Nephrol 1996;28(5):607-13.

6. Chen WP, Lin CY, Hsu HC, Chiang H. Childhood renal diseases in Taiwan. Child NephrolUrol 1988;9(1-2):57-64.

7. CoppoR, Gianogolio B, Porcellini MG, Maringhini S. Frequency of renal diseases and clinical indications for renal diseases in children. Nephrol Dial transplant 1998;13(2):293-7.

8. Ko KW, Ha IS, JinDK, Cheong HI, Choi Y, Kim YI, Lee HS. Childhood renal diseases in Korea- A clinic pathological; study of 657 cases. Paeditrc Nephrol 1987;1(4)664-9.

9. White RHR, Glasgow EF, Mills RJ. Clinico pathological study of nephrotic syndrome in childhood. Lancet 1970;1353-58.

10. Yahya TM, Pingle A, Boobes Y, Pingle S. Analysis of 490 kidney biopsies: data from ther United Arab Emirates renal diseases registry. Journal of Nephrology 1998;11(3):148-50.

11. Absar A, Diamond M, Sonia Y, Arshalooz R, Safi A, Waqar K, et al. Ten year experience of pediatric kidney biopsies from a single center in Pakistan. Indian Journal of Nephrology 2010;20(4):190-2.
12. Diouf B, Ka EF, Niang A, Mbengue M, Ka MM, Diouf ML, Pouye A, Moreira-Diop T. Analysis of 115 kidney biopsies performed in Dakar (Senegal). Dakar Med 2001;46(1)51-3

13. Mc Kinney PA, Feltbower RG, Brocklebank JT, Fitzpatrick MM. Time trends and ethnic patterns of childhood nephrotic syndrome in Yorkshire, UK. Paediatr Nephrol 2001;16(12):1040-4.

14. Yap HK, Murugasu B, Saw AH, Chiang GS, Tay JS, Wong HB, et al. Pattern of glomerulonephritis in Singapore children- a renal biopsy perspective. Ann Acad Med Singapore 1989;18(1):35-9.

15. Briganti EM, Dowling J, Finlay M, Hill PA, Jones CL, Kincaid-Smith PS, et al. The incidence of biopsy proven glomerulonephritis in Australia.Nephrol Dial Transplant 2001;16:1364-7.

16. Woo KT, Chiang GS, Pall A, Tan PH, Lan YK, Chin YM. The changing pattern of glomerulonephritis in Singapore over past two decades. Clin Nephrol 1999;52(2):96-102.

17. Rychik I, Jancova E, Kobsky A, Lacha J. The Czech registry of renal biopsies. Occurrence of renal diseases in the year.Nephrol Dial Transplant 1994-2000;19-24.

18. Lai FM, Lai KN, Chan KW, Au TC, Tong KL, Vallance-Owen J. Pattern of glomerulonephritis in Hong Kong. Pathology 1987;19(3):247-52.

19. Kingswood JC, Banks Ra, Tribe CR, OwenJones, McKenzie JC. Renal biopsy in the elderly: Clinicopathological correlation in 143 patients. ClinNephrol 1984;22(4):183-7.

20. Yoshia K, iijima K, Yoshikawa N. A clinicopathological study of 90 children with acute renal failure. Nippon JinzoGakkaishi 1997;39(5):483-9.

21. Shah BV, Almeida AF, Chawla KP, Shah AB, Mittal BV, Kinare SG, Acharya VN. Acute renal failure in paediatric population in tropics. Journal of Postgraduate Medicine 1985;31(3):134-9.

22. Olowu WA, Adelusola KA. Paediatric acute renal failure in Southwestern Nigeria. Kidney Int 2004;66(4):1541-8.

23. Kazi JI, Akhter F, Ahmed E, Naqvi R, Naqvi SA, Rizvi SA. Spectrum of pathological lesions in acute renal failure. J Coll Physicians surg Pak. 2003;13(1):22-4.

24. Prakash J, Tripathi K, Usha Kumar P. Clinical significance of kidney biopsies in acute renal failure (ARF). Indian J Med Sci 1992;46(11):328-31.

25. Dagger KC, Kopp JB, Egger S, Dagger P. Trends in the epidemiology of focal segmental glomerulosclerosis. Semin Nephrol 200;23(2):172-82.

26. Haas M, Spargo BH, Wit EJ, Meehan SM. Etiologies and outcomes of acute renal insufficiency in older adults: a renal biopsy study of 259 cases. Am J Kidney Dis 2000;35(3):544-6.

27. Kari JA. Early presentation of membranoproliferative glomerulonephritis in Arab children. Saudi med J 2003;24(2):157-60. 
28. Utsumomiya Y, Koda T, Okada S, Hayashi A, Kanzaki S, Kasagi T, et al. Incidence of paediatric IgA nephropathy. Paediatr Nephrol 2003;18(6):511-15.

29. Johnson PA, Brown JS, Braumhottz Da, Davidson AM. Clinico pathological correlations and long term follow-up of United Kingdom patients with IgA nephropathy. QJ Med 1992;84(304):619-27.

30. Riccardo M. New developments in the genetics, pathogenesis and therapy of IgA nephropathy. Kidney International 2015;88:974-89. 